Palimpsest: Journal of Information and Library Science Vol 12, Issue 2, (2021), page 69-84

\title{
Analisis Penggunaan e-DDC dalam Pengklasifikasian Bahan Pustaka di Perpustakaan Lingkungan Universitas Lancang Kuning
}

\section{Analysis The Use of e-DDC in Classification of Library Materials in Environmental Library of The Lancang Kuning University}

\author{
Mutia Afifa Yulia Putri*, Nining Sudiar**, Hadira Latiar*** \\ Library Science, Faculty of Humanities, \\ Lancang Kuning University, Indonesia \\ mutiaafifayuliap@gmail.com
}

\begin{abstract}
Received : $13^{\text {th }}$ October 2021; Revised : $13^{\text {th }}$ November 2021; Accepted : $13^{\text {th }}$ November 2021
\end{abstract}

Available Online : $5^{\text {th }}$ December 2021; Published Regularly : $5^{\text {th }}$ December 2021

\begin{abstract}
As is known, Lancang Kuning University is one of the universities that classify library materials using eDDC. In addition, the librarian's ability to carry out classification activities such as analyzing the subject of existing library materials is necessary for accuracy in determining the subject of library material, knowledge of the DDC's 10 main classes, and the relationship of each science field exists. This research method is descriptive quantitative. The sample in this study is general collections in several libraries at Lancang Kuning University. The results of this study indicate that the highest number of the suitability of collection classification numbers is in the FIB Library, which amounts to 86 collections (88\%, which is in very high criteria). While the lowest number of collection classifications is in the Faculty of Forestry Library, which amounts to 59 collections (62\% and belong to high criteria). A previous study was conducted in 2016 by Dwiyantoro entitled Evaluation of the Use of e-DDC in Classifying Library Materials at the Lancang Kuning University Environmental Library. Therefore it is necessary to carry out an analysis of the classification of library materials again using the newest data to find out the development of the level of suitability of the classification numbers used in libraries at Lancang Kuning University.
\end{abstract}

Keywords: Classification number suitability; e-DDC

\begin{abstract}
Abstrak
Seperti yang diketahui Universitas Lancang Kuning ialah salah satu perguruan tinggi yang dalam kegiatan pengklasifikasian bahan pustakanya menggunakan e-DDC. Di samping itu, kemampuan pustakawan dalam melakukan kegiatan klasifikasi, seperti menganalisis subjek dari bahan pustaka yang ada, sangatlah diperlukan ketelitian dalam penentuan suatu subjek sebuah bahan pustaka, pengetahuan tentang 10 kelas utama dan hubungan dari setiap ilmu pengetahuan yang ada. Metode penelitian ini adalah deskriptif kuantitatif. Sampel pada penelitian ini adalah jumlah koleksi umum yang berada di beberapa perpustakaan di lingkungan Universitas Lancang Kuning. Hasil penelitian ini menunjukkan bahwa jumlah kesesuaian nomor klasifikasi koleksi yang tertinggi berada di Perpustakaan FIB yang berjumlah 86 koleksi $(88 \%$ tergolong dalam kriteria sangat tinggi), sedangkan jumlah kesesuaiaan nomor klasifikasi koleksi yang terendah berada di Perpustakaan Fakultas Kehutanan yang berjumlah 59 koleksi (62\% tergolong dalam kriteria tinggi). Penelitian terdahulu pernah dilakukan oleh Dwiyantoro berjudul Evaluasi Penggunaan e-
\end{abstract}


Palimpsest: Journal of Information and Library Science Vol 12, Issue 1, (2021), page 70-84

DDC dalam Mengklasifikasi Bahan Pustaka di Perpustakaan Lingkungan Universitas Lancang Kuning pada tahun 2016. Maka dari itu, perlu dilakukan analisis pengklasifikasian bahan pustaka kembali untuk mengetahui perkembangan tingkat kesesuaian nomor klasifikasi di perpustakaan-perpustakaan yang ada di lingkungan Universitas Lancang Kuning.

Kata kunci: Kesesuaian nomor klasifikasi; e-DDC

\section{Pendahuluan}

Pengolahan koleksi merupakan bagian penting di dalam suatu perpustakaan. Menurut (Nurfatah, 2016:4) pengolahan koleksi di perpustakaan diawali dari pemeriksaan koleksi yang baru datang sampai koleksi tersebut siap disajikan dan disusun di rak guna dimanfaatkan oleh penggunanya. Salah satu kegiatan pengolahan koleksi perpustakaan yaitu klasifikasi. Tidak dapat dimungkiri bahwa klasifikasi adalah hal yang paling fundamental dalam disiplin ilmu perpustakaan, di mana setiap pustakawan dan siapa pun yang berkecimpung di dunia perpustakaan harus mempunyai pengetahuan dan keahlian yang cukup berkenaan dengan hal tersebut. Di zaman era teknologi ini, ilmu perpustakaan juga berkembang pesat dan memunculkan inovasi baru yakni menciptakan sebuah program yang dipakai sebagai alat untuk mengklasifikasi bahan pustaka. Klasifikasi dahulunya menggunakan pedoman buku tercetak atau manual sekarang berbentuk digital yang disebut e-DDC (Electronic Dewey Decimal Classification). eDDC pada dasarnya merupakan bentuk digital dari DDC. e-DDC bertujuan untuk membantu penggiat perpustakaan dan pustakawan untuk menentukan nomor klasifikasi DDC dengan cara yang lebih mudah dan praktis termasuk aplikasi freeware. Sejak pertama kali dirilis pada tahun 2010 yaitu e-DDC versi 1.1 aplikasi perangkat lunak e-DDC kini sudah berkembang pada versi ke-3, yaitu Edition 23.

Seperti yang diketahui Universitas Lancang Kuning (Unilak) ialah salah satu perguruan tinggi dalam kegiatan pengklasifikasian bahan pustakanya menggunakan e-DDC. Di samping itu, kemampuan pustakawan dalam melakukan kegiatan klasifikasi seperti menganalisis subjek dari bahan pustaka yang ada sangatlah diperlukan. Diperlukan ketelitian dalam penentuan suatu subjek sebuah bahan pustaka, pengetahuan tentang 10 kelas utama dan hubungan dari setiap ilmu pengetahuan yang ada. Untuk mengetahui apakah pustakawan memahami tentang penggunaan eDDC, perlu adanya analisis kegiatan klasifikasi terhadap penggunaan aplikasi e-DDC tepatnya di perpustakaan Lingkungan Universitas Lancang Kuning. Penelitian terdahulu yang pernah dilakukan oleh Dwiyantoro berjudul Evaluasi Penggunaan e-DDC dalam Mengklasifikasi Bahan Pustaka di Perpustakaan Lingkungan Universitas Lancang Kuning pada tahun 2016, maka dari itu perlu dilakukan analisis pengklasifikasian bahan pustaka kembali di perpustakaan lingkungan Unilak. Dari delapan perpustakaan di lingkungan Unilak, penulis mengambil enam perpustakaan yaitu UPT Perpustakaan Unilak, Perpustakaan Fakultas Ilmu Budaya (FIB), Perpustakaan Fakultas Kehutanan, Perpustakaan Fakultas Ilmu Ekonomi (Fekon), Perpustakaan Fakultas Administrasi (FIA), dan Perpustakaan Fakultas Hukum. Namun dalam kegiatan pengklasifikasian bahan pustaka penulis menemukan beberapa ketidaksesuain nomor klasifikasi di beberapa perpustakaan tersebut, contohnya di UPT Perpustakaan Unilak. Buku dengan judul "Ilmu Budaya Dasar" dengan nomor klasifikasi 001.42, seharusnya nomor klasifikasi buku tersebut yaitu 306 karena "Ilmu Budaya Dasar" termasuk ke dalam kelas 300 bukan 000. Untuk itu perlu menganalisis Kembali penggunaan e-DDC terhadap pengklasifikasian koleksi yang berada di perpustakaan yang ada pada lingkungan Unilak. 
Palimpsest: Journal of Information and Library Science Vol 12, Issue 2, (2021), page 71-84

\section{Kajian Pustaka}

Penelitian yang dilakukan oleh Dwiyantoro (2016) dengan judul Evaluasi Penggunaan eDDC dalam Mengklasifikasi Bahan Pustaka di Lingkungan Perpustakaan Universitas Lancang Kuning. Penelitian ini merupakan skripsi di Fakultas Ilmu Budaya Unilak tahun 2016. Tujuan dari penelitian ini ialah untuk mengevaluasi penggunaan e-DDC dalam mengklasifikasi bahan pustaka di lingkungan Perpustakaan Unilak. Hasil dari penelitian ini menunjukkan bahwa dari keempat perpustakaan yang dijadikan sampel, perpustakaan yang memiliki data persentase 2140\% dengan ketidaksesuaian nomor klasifikasi dapat dikatakan rendah yaitu perpustakaan Fakultas Ilmu Administrasi (FIA) sebesar (21,27\%) dan Perpustakaan Fakultas Ilmu Budaya (FIB) dengan persentase sebesar $(22,72 \%)$. Sedangkan untuk perpustakaan yang memiliki ketidaksesuaian nomor klasifikasi dengan data persentase (41-60\%) dapat dikatakan sedang yaitu UPT Perpustakaan Unilak sebesar (41,23\%), dan Perpustakaan Fakultas Hukum dengan persentase sebesar (45,83\%). Jenis penelitian ini ialah deskriptif kuantitatif. Penelitian ini dilakukan dari bulan Februari 2016 sampai April 2016. Subjek penelitian ini adalah nomor klasifikasi yang ada di UPT Perpustakaan Unilak dengan jumlah sampel 97 judul, Perpustakaan FIB dengan jumlah sampel 88 judul, Perpustakaan FIA dengan jumlah sampel 94 judul, dan Perpustakaan Fakultas Hukum dengan jumlah sampel 96 judul.

\section{Metode Penelitian}

Jenis penelitian ini ialah deskriptif dan menggunakan pendekatan kuantitatif. Menurut Sugiyono (2011:7), penelitian kuantitatif ialah penelitian yang diperoleh menggunakan data dan bentuk angka dan analisis menggunakan statistik. Pada penelitian ini penulis menggunakan beberapa teknik pengumpulan data yakni observasi, dokumentasi, wawancara, dan studi pustaka. Analisis ini diolah dengan teknik persentasi Arikunto (2003:57) melalui rumus,

$$
P=\frac{f}{N} \times 100 \%
$$

Keterangan:

P : Angka Persentase

f : Frekuensi

N : Jumlah Keseluruhan Koleksi

100\% : Bilangan Tetap

Penafsiran data dilakukan menggunakan kriteria persentase yang dikemukakan (Arikunto, 2003:57) berikut ini,

$81-100 \% \quad$ : Sangat Tinggi

$61-80 \% \quad$ : Tinggi

$41-60 \% \quad:$ Sedang

$21-40 \% \quad:$ Rendah

$0-20 \% \quad$ : Sangat rendah

\section{Hasil dan Pembahasan}

Penelitian ini dilakukan dengan cara mengumpulkan jumlah koleksi umum di beberapa perpustakaan yaitu UPT Perpustakaan Unilak, Perpustakaan FIB, Perpustakaan Fakultas Hukum, 
Perpustakaan Fekon, Perpustakaan FIA, dan Perpustakaan Fakultas Kehutanan. Kemudian diambil sampel dari jumlah koleksi umum yang terdapat di beberapa perpustakaan tersebut. Setelah pengambilan sampel secara acak berdasarkan 10 kelas utama selanjutnya dilakukan pengecekan terhadap nomor klasifikasi melalui aplikasi e-DDC. Berikut merupakan jumlah koleksi umum yang diteliti dari beberapa perpustakaan di lingkungan Unilak,

Tabel 1.

Jumlah koleksi

\begin{tabular}{clc}
\hline No & \multicolumn{1}{c}{ Nama perpustakaan } & Jumlah koleksi \\
\hline 1 & UPT Perpustakaan Unilak & 99 \\
2 & Perpustakaan FIB & 98 \\
3 & Perpustakaan Fakultas Hukum & 98 \\
4 & Perpustakaan Fekon & 97 \\
5 & Perpustakaan FIA & 96 \\
6 & Perpustakaan Fakultas Kehutanan & 95 \\
\hline
\end{tabular}

Sumber: UPT Perpustakaan Unilak, Perpustakaan FIB, Perpustakaan Fakultas Hukum, Perpustakaan Fekon, Perpustakaan FIA, dan Perpustakaan Fakultas Kehutanan.

Pada tabel 1 dapat dilihat bahwa jumlah koleksi umum yang diteliti pada UPT Perpustakaan Unilak 99 koleksi, Perpustakaan 98 koleksi, Perpustakaan Fakultas Hukum 98 koleksi, Perpustakaan Fekon 97 koleksi, Perpustakaan FIA 96 koleksi, dan Perpustakaan Fakultas Kehutanan 95 koleksi.

\section{Nomor Klasifikasi Koleksi UPT Perpustakaan Universitas Lancang Kuning}

Tabel 2.

Jumlah nomor klasifikasi koleksi UPT Perpustakaan Unilak yang sesuai dan tidak sesuai

\begin{tabular}{|c|c|c|c|c|c|c|}
\hline \multirow{2}{*}{ No. } & \multirow{2}{*}{ No. Kelas } & \multirow{2}{*}{ Jumlah } & \multicolumn{2}{|c|}{ Sesuai } & \multicolumn{2}{|c|}{ Tidak sesuai } \\
\hline & & & $\mathbf{F}$ & $\%$ & $\mathbf{F}$ & $\%$ \\
\hline 1. & 000 & 11 & 7 & $64 \%$ & 4 & $36 \%$ \\
\hline 2. & 100 & 10 & 9 & $90 \%$ & 1 & $10 \%$ \\
\hline 3. & 200 & 10 & 4 & $40 \%$ & 6 & $60 \%$ \\
\hline 4. & 300 & 10 & 10 & $100 \%$ & 0 & 0 \\
\hline 5. & 400 & 10 & 9 & $90 \%$ & 1 & $10 \%$ \\
\hline 6. & 500 & 12 & 9 & $75 \%$ & 3 & $25 \%$ \\
\hline 7. & 600 & 11 & 10 & $91 \%$ & 1 & $9 \%$ \\
\hline 8. & 700 & 10 & 8 & $80 \%$ & 2 & $20 \%$ \\
\hline 9. & 800 & 11 & 10 & $91 \%$ & 1 & 0 \\
\hline 10. & 900 & 4 & 4 & $100 \%$ & 0 & 0 \\
\hline & Jumlah & 99 & 80 & & 19 & \\
\hline & Total \% & & $81 \%$ & & $19 \%$ & \\
\hline
\end{tabular}

Sumber: Data diolah Mei 2021

Dari hasil tabel 2 dapat disimpulkan jumlah keseluruhan sampel yang diteliti di UPT Perpustakaan Unilak dari ke 10 kelas utama ditemui jumlah kesesuaian dan ketidaksesuaian dengan jumlah $f$ yang bervariasi. Peneliti akan mengambil 2 kelas utama dari uraian di atas lalu sampel yang diambil yakni kelas yang memiliki nomor klasifikasi kesesuaian tertinggi dan kelas 
yang memiliki nomor klasifikasi tidak sesuai tertinggi.

Selanjutnya dapat disimpulkan dari penjelasan di atas yaitu seluruh koleksi yang dengan total 99 koleksi diketahui dari analisis data persentase tingkat kesesuaian sekitar 81-100\% dikatakan sangat tinggi ialah $81 \%$ sedangkan tingkat tidak sesuai koleksi sekitar 0-20\% termasuk dalam kriteria sangat rendah yaitu $19 \%$.

Kesesuaian nomor klasifikasi terbanyak terdapat pada kelas 300 dan 900, berdasarkan analisis data persentase sejumlah $81-100 \%$ diartikan sangat tinggi. Lalu ketidaksesuaian nomor klasifikasi terbanyak terdapat di kelas 200, berdasarkan analisis data persentase sejumlah 21-40\% ditafsikan rendah. Untuk mengetahui nomor klasifikasi yang tidak sesuai berdasarkan divisi pada kelas 200 diketahui sebagai berikut,

Tabel 3.

Jumlah ketidaksesuaian nomor klasifikasi kelas 200 digolongkan berdasarkan divisi

\begin{tabular}{|c|c|c|c|c|}
\hline No. & Divisi & Judul & $\begin{array}{c}\text { Nomor } \\
\text { Klasifikasi } \\
\text { Sampel }\end{array}$ & $\begin{array}{l}\text { Nomor Klasifikasi } \\
\text { Sampel yang Sesuai }\end{array}$ \\
\hline \multirow[t]{6}{*}{1.} & 297 & Filsafat Hukum Islam & 297.401 & 297.261 \\
\hline & & $\begin{array}{l}\text { Hikmah Dibalik Perintah dan Larangan } \\
\text { Allah }\end{array}$ & 297.401 & 297.07 \\
\hline & & Penelitian Agama Islam & 297.67 & 297.07 \\
\hline & & Sejarah Pendidikan Islam & 297.64 & 297.6 \\
\hline & & Akhlak Tasawuf dan Karakter Mulia & 297.5 & 297.41 \\
\hline & & Islam Untuk Disiplin Ilmu Hokum & 297.4 & 297.272 \\
\hline
\end{tabular}

Sumber: Data diolah Mei 2021

Pada tabel 3 terdapat nomor klasifikasi yang mempunyai ketidaksesuaian pada kelas 200 terdapat pada 1 divisi yaitu divisi 297. Agar memahami tabel di atas dilihat dari contoh koleksi yang berjudul Filsafat Hukum Islam mempunyai nomor klasifikasi 297.401, sedangkan nomor klasifikasi yang sesuai yaitu 297.261, kedua nomor klasifikasi tersebut terdapat perbedaan notasi 261 pada nomor klasifikasi yang sesuai. Nomor klasifikasi sampel yaitu 297.401 menjelaskan tentang Sufism/Sufisme, Sufi kelaskan di sini sufistik, mistik islam. Untuk memahami nomor klasifikasi yang sesuai dapat dilihat pada keterangan dibawah:

Judul

: Filsafat Hukum Islam

Subjek

: Islam

Keterangan

: 297.261 Islam and Philosophy/Islam dan Filsafat, Filsafat Islam

Kelaskan di sini pandangan islam terhadap psikologi, pandangan islam terhadap parapsikologi dan ilmu ghaib.

Nomor Klasifikasi $\quad$ : 297.261

Nomor Klasifikasi Koleksi Perpustakaan FIB Universitas Lancang Kuning

Tabel 4.

Jumlah nomor klasifikasi koleksi Perpustakaan FIB Unilak yang sesuai dan tidak sesuai

\begin{tabular}{ccccccc}
\hline \multirow{2}{*}{ No. } & \multirow{2}{*}{ No. Kelas } & \multirow{2}{*}{ Jumlah } & \multicolumn{2}{c}{ Sesuai } & \multicolumn{2}{c}{ Tidak sesuai } \\
& & & F & \% & F & \% \\
\hline 1. & 000 & 7 & 7 & $\mathbf{1 0 0 \%}$ & 0 & $\mathbf{0 \%}$
\end{tabular}


Palimpsest: Journal of Information and Library Science Vol 12, Issue 1, (2021), page 74-84

\begin{tabular}{clccccc}
\hline \multirow{2}{*}{ No. } & \multirow{2}{*}{ No. Kelas } & \multirow{2}{*}{ Jumlah } & \multicolumn{2}{c}{ Sesuai } & \multicolumn{2}{c}{ Tidak sesuai } \\
& & & F & \% & F & \% \\
\hline 2. & 100 & 8 & 7 & $\mathbf{8 8 \%}$ & 1 & $\mathbf{1 3 \%}$ \\
3. & 200 & 9 & 9 & $\mathbf{1 0 0 \%}$ & 0 & $\mathbf{0 \%}$ \\
4. & 300 & 15 & 14 & $\mathbf{9 3 \%}$ & 1 & $\mathbf{7 \%}$ \\
5. & 400 & 12 & 11 & $\mathbf{9 2 \%}$ & 1 & $\mathbf{8 \%}$ \\
6. & 500 & 6 & 4 & $\mathbf{6 7 \%}$ & 2 & $\mathbf{3 3 \%}$ \\
7. & 600 & 10 & 6 & $\mathbf{6 0 \%}$ & 4 & $\mathbf{0 \%}$ \\
8. & 700 & 10 & 9 & $\mathbf{9 0 \%}$ & 1 & $\mathbf{1 0 \%}$ \\
9. & 800 & 12 & 11 & $\mathbf{9 2 \%}$ & 1 & $\mathbf{8 \%}$ \\
10. & 900 & 9 & 8 & $\mathbf{8 9 \%}$ & 1 & $\mathbf{1 1 \%}$ \\
\hline & Jumlah & $\mathbf{9 8}$ & $\mathbf{8 6}$ & \multicolumn{3}{c}{$\mathbf{1 2}$} \\
\hline & Total \% & \multicolumn{3}{c}{$88 \%$} & & $12 \%$ \\
\hline
\end{tabular}

Sumber: Data diolah Mei 2021

Dari tabel 4 dapat ditarik kesimpulan bahwa dari jumlah keseluruhan sampel yang diteliti di Perpustakaan FIB terdapat beberapa kelas menurut 10 kelas utama yang mempunyai total kesesuaian dan ketidaksesuaian dengan jumlah $f$ bervariasi. Dari tabel di atas peneliti hanya akan mengambil 2 kelas utama yang akan dijadikan sampel ialah kelas yang memiliki nomor klasifikasi yang jumlah kesesuaian tertinggi dan kelas yang memiliki nomor klasifikasi yang jumlah ketidaksesuaian tertinggi.

Berdasarkan penjelasan tersebut diketahui bahwa keseluruhan koleksi berjumlah 98 koleksi tingkat kesesuaian ditafsirkan dari analisis data persentase sekitar $81-100 \%$ ditafsirkan sangat tinggi $88 \%$ sedangkan tingkat tidak sesuai koleksi sekitar 0-20\% termasuk dalam kriteria sangat rendah yaitu $12 \%$.

Kesesuaian nomor klasifikasi terbanyak terdapat pada kelas 300, 400 dan 800, berdasarkan analisa persentase data sekitar $81-100 \%$ dikatakan sangat tinggi. Ketidaksesuaian nomor klasifikasi terbanyak terdapat pada kelas 600, menurut analisis persentase data sekitar 0-20\% tergolong sangat rendah. Agar lebih memahami ketidaksesuaian koleksi yang terdapat pada kelas 600 menurut divisi diketahui sebagai berikut,

Tabel 5.

Jumlah ketidaksesuaian nomor klasifikasi kelas 600 digolongkan berdasarkan divisi

\begin{tabular}{|c|c|c|c|c|}
\hline No & Divisi & Judul & $\begin{array}{c}\text { Nomor } \\
\text { Klasifikasi } \\
\text { Sampel }\end{array}$ & $\begin{array}{l}\text { Nomor Klasifikasi } \\
\text { Sampel yang Sesuai }\end{array}$ \\
\hline \multirow{3}{*}{1} & & Bioteknologi Kelautan & 620.41 & 660.616 .2 \\
\hline & $620-629$ & Mempercepat Kinerja Computer & 620.82 & 621.382 \\
\hline & & $\begin{array}{l}\text { Manajemen Dokumen Ilmiah } \\
\text { (Menggunakan Zetero dan Mendeley) }\end{array}$ & 651.59 & 651.8 \\
\hline 2 & $650-659$ & Manajemen Organisasi Seni Pertunjukan & 658.04 & 658.790 .2 \\
\hline
\end{tabular}

Sumber: Data diolah Mei 2021

Berdasarkan tabel 5 diuraikan bahwa nomor klasifikasi yang mempunyai ketidaksesuaian terbanyak terdapat di kelas 600 , lalu kelas tersebut dibagi menjadi beberapa divisi untuk memahami tabel di atas dijelaskan contoh koleksi dengan judul Manajemen Dokumen Ilmiah 
(Menggunakan Zetero dan Mendeley) dengan nomor klasifikasi 651.59, sedangkan nomor klasifikasi yang tepat ialah 651.8, berdasarkan kedua nomor klasifikasi di atas terdapat perbedaan yaitu subdivisi 651 di nomor klasifikasi yang sesuai. Untuk memahami nomor klasifikasi yang sesuai dapat dijelaskan pada keterangan berikut,

$\begin{array}{ll}\text { Judul } & : \text { Manajemen Dokumen Ilmiah (Menggunakan Zetero dan Mendeley) } \\ \text { Subjek } & : \text { Manajemen } \\ \text { Keterangan } & : \text { 651.8 Computer Application For Office Management/ Aplikasi } \\ & \text { Komputer Untuk Manajemen Perkantoran }\end{array}$

Nomor Klasifikasi

Kelaskan di sini pengolahan dan analisa data di bidang manajemen perkantoran, komputerisasi perkantoran.

\section{Nomor Klasifikasi Koleksi Perpustakaan Fakultas Hukum Universitas Lancang Kuning}

Tabel 6.

Jumlah nomor klasifikasi koleksi Perpustakaan Fakultas Hukum Unilak yang sesuai dan tidak sesuai

\begin{tabular}{clccccc}
\hline \multirow{2}{*}{ No. } & \multirow{2}{*}{ No. Kelas } & \multirow{2}{*}{ Jumlah } & \multicolumn{2}{c}{ Sesuai } & \multicolumn{2}{c}{ Tidak sesuai } \\
& & & F & $\mathbf{\%}$ & F & \% \\
\hline 1. & 000 & 0 & 0 & $\mathbf{0 \%}$ & 0 & $\mathbf{0 \%}$ \\
2. & 100 & 0 & 0 & $\mathbf{0 \%}$ & 0 & $\mathbf{0 \%}$ \\
3. & 200 & 0 & 0 & $\mathbf{0 \%}$ & 0 & $\mathbf{0 \%}$ \\
4. & 300 & 98 & 71 & $\mathbf{7 2 \%}$ & 27 & $\mathbf{2 8 \%}$ \\
5. & 400 & 0 & 0 & $\mathbf{0 \%}$ & 0 & $\mathbf{0 \%}$ \\
6. & 500 & 0 & 0 & $\mathbf{0 \%}$ & 0 & $\mathbf{0 \%}$ \\
7. & 600 & 0 & 0 & $\mathbf{0 \%}$ & 0 & $\mathbf{0 \%}$ \\
8. & 700 & 0 & 0 & $\mathbf{0 \%}$ & 0 & $\mathbf{0 \%}$ \\
9. & 800 & 0 & 0 & $\mathbf{0 \%}$ & 0 & $\mathbf{0 \%}$ \\
10. & 900 & 0 & 0 & $\mathbf{0 \%}$ & 0 & $\mathbf{0 \%}$ \\
\hline \multicolumn{2}{c}{ Jumlah } & $\mathbf{9 8}$ & $\mathbf{7 1}$ & \multicolumn{4}{c}{$\mathbf{2 7}$} \\
\multicolumn{2}{c}{ Total \% } & & $72 \%$ & & $28 \%$ \\
\hline
\end{tabular}

Sumber: Data diolah Mei 2021

Pada tabel 6 diperoleh kesimpulan yakni dari keseluruhan sampel yang diteliti di Perpustakaan Fakultas Hukum Unilak terdapat beberapa kelas berdasarkan 10 kelas utama yang mempunyai kesesuaian lalu tidak sesuai berjumlah $f$ yang bervariasi. Dari pemaparan di atas akan diambil 2 kelas utama yang akan diambil sampel yaitu kelas yang memiliki nomor klasifikasi yang kesesuaian terbanyak dan kelas yang memiliki nomor klasifikasi tidak sesuai terbanyak.

Menurut penjelasan tersebut maka total koleksi yang berjumlah 98 koleksi yang tingkat kesesuaian dapat diketahui dari analisis data persentase sekitar 61-80\% diartikan tinggi yaitu 72\% akan tetapi tingkat tidak sesuai koleksi sebesar 21-40\% termasuk kriteria rendah yaitu $28 \%$.

Kesesuaian nomor klasifikasi terbanyak yaitu kelas 300. Berdasarkan analisis data persentase sekitar 61-80\% dikatakan tinggi. Lalu ketidaksesuaian nomor klasifikasi berdasarkan analisis data persentase sekitar 21-40\% ditafsirkan rendah. Untuk memahami ketidaksesuaian koleksi di kelas 300 dijelaskan menurut divisi sebagai berikut,

Tabel 7. 
Palimpsest: Journal of Information and Library Science Vol 12, Issue 1, (2021), page 76-84

Jumlah ketidaksesuaian nomor klasifikasi kelas 300 digolongkan berdasarkan divisi

\begin{tabular}{|c|c|c|c|c|}
\hline No. & Divisi & Judul & $\begin{array}{c}\text { Nomor } \\
\text { Klasifikasi } \\
\text { Sampel } \\
\end{array}$ & $\begin{array}{c}\text { Nomor } \\
\text { Klasifikasi yang } \\
\text { Sesuai } \\
\end{array}$ \\
\hline \multirow[t]{20}{*}{1.} & \multirow[t]{20}{*}{$340-349$} & Sistem Hukum dan Tata Hukum Indonesia & 340 & 340.598 \\
\hline & & Hukum Adat, Dahulu, Kini dan Akan Datang & 340.57 & 340.5 \\
\hline & & $\begin{array}{l}\text { Hak Milik Intelektual, Sejarah, Teori dan } \\
\text { Prakteknya di Indonesia }\end{array}$ & 341.758 & 346.04 \\
\hline & & $\begin{array}{l}\text { Tindak Pidana Terhadap Hak Atas Kekayaan } \\
\text { Intelektual }\end{array}$ & 341.758 & 346.04 \\
\hline & & Ilmu Pemerintahan & 342 & 320 \\
\hline & & $\begin{array}{l}\text { Hukum Perizinan dalam Sektor Pelayanan } \\
\text { Publik }\end{array}$ & 342 & 343.02 \\
\hline & & $\begin{array}{l}\text { Perkembangan \& Konsolidasi Lembaga } \\
\text { Negara Pasca Reformasi }\end{array}$ & 342 & 340.3 \\
\hline & & Hukum Perburuhan, Perjanjian Kerja & 344.01 & 344. 0101 \\
\hline & & Kejahatan Mengenai Pemalsuan & 345 & 364.163 \\
\hline & & Pengantar Kriminologi & 345 & 364 \\
\hline & & Ruang Lingkup Kriminologi & 345 & 364 \\
\hline & & Pengantar Kriminologi dan Patologi Sosial & 345 & 364 \\
\hline & & Teori dan Kapita Selekta Kriminologi & 345 & 364 \\
\hline & & $\begin{array}{l}\text { Illegal Logging, dalam Perspektik Politik } \\
\text { Hukum Pidana (Kasus Papua) }\end{array}$ & 345 & 364.1 \\
\hline & & $\begin{array}{l}\text { Penerapan Pembuktian Terbalik dalam Delik } \\
\text { Korupsi (UU No. } 20 \text { Tahun 2001) }\end{array}$ & 345.05 & 345.01 \\
\hline & & $\begin{array}{l}\text { Tindak Pidana Masyarakat, Perkembangan } \\
\text { Kajian Cyber Crime di Indonesia }\end{array}$ & 345.026 & 345.598 \\
\hline & & Hukum Perkawinan Nasional & 346.02 & 346.01 \\
\hline & & $\begin{array}{l}\text { Kekerasan dalam Rumah Tangga, dalam } \\
\text { Perspektif Yuridis-Viktimologis }\end{array}$ & 346.015 & 346.01 \\
\hline & & Teknik Pembuatan Akta Perjanjian & 346.0023 & 346.02 \\
\hline & & Hukum Acara Persaingan Usaha di Indonesia & 346.08 & 346.07 \\
\hline \multirow[t]{6}{*}{2.} & \multirow[t]{6}{*}{$350-359$} & Otonomi Daerah (dalam Negara Kesatuan) & 352 & 352.14 \\
\hline & & Pokok-Pokok Hukum Pemerintahan Daerah & 352 & 352.14 \\
\hline & & Desentralisasi \& Otonomi Daerah & 352 & 352.14 \\
\hline & & $\begin{array}{l}\text { Memandu Otonomi Daerah Menjaga Kesatuan } \\
\text { Bangsa }\end{array}$ & 352 & 352.14 \\
\hline & & Otonomi Daerah (dalam Negara Kesatuan) & 352 & 352.14 \\
\hline & & Pokok-Pokok Hukum Pemerintahan Daerah & 352 & 352.14 \\
\hline 3. & 380-389 & $\begin{array}{l}\text { Prinsip-Prinsip Perlindungan Hukum bagi } \\
\text { Konsumen di Indonesia }\end{array}$ & 381.34 & 381.3 \\
\hline
\end{tabular}


Palimpsest: Journal of Information and Library Science Vol 12, Issue 2, (2021), page 77-84

Menurut tabel 7 diketahui yaitu nomor klasifikasi yang mempunyai ketidaksesuaian tertinggi terdapat di kelas 300, kemudian kelas tersebut dibagi menjadi 3 divisi untuk memahami tabel 13 dilihat pada contoh judul koleksi Sistem Hukum dan Tata Hukum Indonesia dengan nomor klasifikasi 340, sedangkan nomor klasifikasi yang sesuai adalah 340.598, kedua nomor klasifikasi tersebut terdapat perbedaan notasi pada nomor klasifikasi yang sesuai. Nomor klasifikasi sampel yaitu 340 menjelaskan tentang Law/Ilmu hukum. Untuk melihat nomor klasifikasi yang sesuai dilihat pada penjelasan berikut ini:

$\begin{array}{ll}\text { Judul } & : \text { Sistem Hukum dan Tata Hukum Indonesia } \\ \text { Subjek } & : \text { Hukum } \\ \text { Tabel 2 (Wilayah) } & : \text { :598 Indonesia }\end{array}$

Keterangan

: 340 Law/Ilmu Hukum

Kelaskan di sini juga jurisprudensi/yurisprudensi

Nomor Klasifikasi $\quad: 340.598$

\section{Nomor Klasifikasi Koleksi Perpustakaan Fakultas Ekonomi (Fekon) Universitas Lancang Kuning Tabel 8.}

Jumlah nomor klasifikasi koleksi Perpustakaan Fekon Unilak yang sesuai dan tidak sesuai

\begin{tabular}{|c|c|c|c|c|c|c|}
\hline \multirow{2}{*}{ No. } & \multirow{2}{*}{ No. Kelas } & \multirow{2}{*}{ Jumlah } & \multicolumn{2}{|c|}{ Sesuai } & \multicolumn{2}{|c|}{ Tidak Sesuai } \\
\hline & & & $\mathbf{F}$ & $\%$ & $\mathbf{F}$ & $\%$ \\
\hline 1. & 000 & 2 & 0 & $100 \%$ & 0 & $0 \%$ \\
\hline 2. & 100 & 0 & 0 & $0 \%$ & 0 & $0 \%$ \\
\hline 3. & 200 & 10 & 9 & $90 \%$ & 1 & $10 \%$ \\
\hline 4. & 300 & 44 & 32 & $73 \%$ & 12 & $27 \%$ \\
\hline 5. & 400 & 0 & 0 & $0 \%$ & 0 & $0 \%$ \\
\hline 6. & 500 & 0 & 0 & $0 \%$ & 0 & $0 \%$ \\
\hline 7. & 600 & 39 & 30 & $77 \%$ & 9 & $23 \%$ \\
\hline 8. & 700 & 0 & 0 & $0 \%$ & 0 & $0 \%$ \\
\hline 9. & 800 & 0 & 0 & $0 \%$ & 0 & $0 \%$ \\
\hline 10. & 900 & 2 & 2 & $100 \%$ & 0 & $0 \%$ \\
\hline & Jumlah & 97 & 75 & & 22 & \\
\hline & Total \% & & $77 \%$ & & $23 \%$ & \\
\hline
\end{tabular}

Sumber: Data diolah Mei 2021

Berdasarkan tabel 8 dapat diketahui jumlah keseluruhan dari sampel yang diteliti di Perpustakaan Fekon Unilak dari sepuluh kelas utama ditemui sebagian kelas mempunyai jumlah sesuai dan yang tidak sesuai dapat dikatakan jumlah $f$ beraneka ragam. Menurut penjelasan di atas peneliti hanya mengambil 2 kelas utama diambil sampel yaitu kelas yang memiliki nomor klasifikasi dengan jumlah kesesuaian tertinggi dan nomor klasifikasi kelas yang mempunyai jumlah tidak sesuai terbanyak.

Menurut penjelasan di atas total koleksi yang berjumlah 97 koleksi tingkat kesesuaian dilihat dari analisis data persentase berkisar $61-80 \%$ diartikan tinggi yaitu $77 \%$ lalu tingkat tidak sesuai koleksi sebesar 21-40\% termasuk dalam kriteria rendah yakni $23 \%$.

Kesesuaian nomor klasifikasi terbanyak terdapat di kelas 300. Berdasarkan analisis persentase sekitar 61-80\% ditafsirkan tinggi. Selanjutnya ketidaksesuaian nomor klasifikasi berdasarkan analisis data persentase sekitar 21-40\% dikatakan rendah. Agar mengetahui koleksi 
yang tidak sesuai pada kelas 300 dilihat berdasarkan divisi sebagai berikut,

Tabel 9.

Jumlah ketidaksesuaian nomor klasifikasi kelas 300 digolongkan berdasarkan divisi

\begin{tabular}{lllll}
\hline No. & \multirow{2}{*}{ Divisi } & \multicolumn{1}{c}{ Judul } & $\begin{array}{c}\text { Nomor } \\
\text { Klasifikasi } \\
\text { Sampel }\end{array}$ & $\begin{array}{c}\text { Nomor Klasifikasi } \\
\text { yang Sesuai }\end{array}$ \\
& & 300 & 338 \\
\hline 1. & $300-309$ & Ekonomi industry & 303.34 & 300.6 \\
& & Kepemimpinan dalam manajemen & 330 & 338.06 \\
2. & $330-339$ & Studi kelayakan bisnis & 330 & 330.01 \\
& & Ekonomi Internasional Teori dan Kebijakan & 331 & 331.7 \\
& & Solusi praktis bagi manajer & 336.85 & 338.5 \\
& & Mikroekonomi teori pengantar & 338.9 & 330.112 \\
& & Krisis kapitalisme global & 339.09598 & 339.598 \\
& & Formasi mikro-makro ekonomi Indonesia & 338.9 & 330.112 \\
3. & Teori ekonomi mikro & 370 & 371.1 \\
4. & Guru pahlawan tanpa tanda jasa & 381.13 & 658.87 \\
& $380-389$ & Seri hukum bisnis waralaba & & \\
& & GATT dan WTO, Sistem, Forum dan Lembaga & 382.92 & 382.9 \\
\hline
\end{tabular}

Sumber: Data diolah Mei 2021

Berdasarkan tabel 9 dapat diuraikan yaitu nomor klasifikasi pada kelas 300 memiliki ketidaksesuaian terbanyak, lalu dibagi 4 divisi dari kelas tersebut untuk menelaah penjelasan di atas dapat dilihat pada koleksi dengan contoh judul Ekonomi Industri yaitu nomor klasifikasi 300, sedangkan nomor klasifikasi yang benar adalah 338, kedua nomor klasifikasi tersebut terdapat perbedaan divisi pada nomor klasifikasi yang sesuai. Nomor klasifikasi sampel yaitu 300 menjelaskan tentang Social Science/Ilmu Sosial. Dapat dilihat keterangan di bawah ini untuk mengetahui nomor klasifikasi yang sesuai,

Judul : Ekonomi Industri

Subjek : : $\quad$ : 338 Pronomi

Keterangan : 338 Production, Industrial Economics/Produksi Ekonomi Industri Perhatikan 670-679 untuk pabrik-pabrik dan 680-689 untuk produksi khusus.

Nomor Klasifikasi $\quad: 338$

\section{Nomor Klasifikasi Koleksi Perpustakaan Fakultas Administrasi (FIA) Universitas Lancang Kuning}

Tabel 10.

Jumlah nomor klasifikasi koleksi umum Perpustakaan FIA Unilak yang sesuai dan tidak sesuai

\begin{tabular}{clccccc}
\hline \multirow{2}{*}{ No. No. Kelas } & \multirow{2}{*}{ Jumlah } & \multicolumn{2}{c}{ Sesuai } & \multicolumn{2}{c}{ Tidak sesuai } \\
& & & F & \% & F & \% \\
\hline 1. & 000 & 10 & 6 & $\mathbf{6 0 \%}$ & 4 & $\mathbf{4 0 \%}$ \\
2. & 100 & 12 & 11 & $\mathbf{9 2 \%}$ & 1 & $\mathbf{8 \%}$ \\
3. & 200 & 0 & 0 & $\mathbf{0 \%}$ & 0 & $\mathbf{0 \%}$ \\
4. & 300 & 39 & 34 & $\mathbf{7 9 \%}$ & 8 & $\mathbf{2 1 \%}$
\end{tabular}


Palimpsest: Journal of Information and Library Science Vol 12, Issue 2, (2021), page 79-84

\begin{tabular}{clccccc}
\hline \multirow{2}{*}{ No. } & \multirow{2}{*}{ No. Kelas } & \multirow{2}{*}{ Jumlah } & \multicolumn{2}{c}{ Sesuai } & \multicolumn{2}{c}{ Tidak sesuai } \\
& & F & $\mathbf{\%}$ & F & \% \\
\hline 5. & 400 & 0 & 0 & $\mathbf{0 \%}$ & 0 & $\mathbf{0 \%}$ \\
6. & 500 & 3 & 3 & $\mathbf{1 0 0 \%}$ & 0 & $\mathbf{0 \%}$ \\
7. & 600 & 24 & 17 & $\mathbf{7 1 \%}$ & 7 & $\mathbf{2 9 \%}$ \\
8. & 700 & 0 & 0 & $\mathbf{0 \%}$ & 0 & $\mathbf{0 \%}$ \\
9. & 800 & 1 & 1 & $\mathbf{1 0 0 \%}$ & 0 & $\mathbf{0 \%}$ \\
10. & 900 & 7 & 7 & $\mathbf{1 0 0 \%}$ & 0 & $\mathbf{0 \%}$ \\
\hline \multicolumn{3}{c}{ Jumlah } & $\mathbf{9 6}$ & $\mathbf{7 7}$ & $\mathbf{1 9}$ \\
\hline \multicolumn{5}{c}{ Total \% } & $80 \%$ \\
\hline \multicolumn{3}{c}{$20 \%$} \\
\hline \multicolumn{3}{c}{ Sumber: Data diolah Mei 2021 }
\end{tabular}

Menurut tabel 10 dapat dijelaskan bahwa jumlah dari keseluruhan sampel yang diteliti di Perpustakaan FIA Unilak terdapat beberapa kelas dari 10 kelas utama yang mempunyai total kesesuaian dan tidak sesuai dengan jumlah $f$ yang bermacam. Kemudian hanya akan mengambil 2 kelas utama yang nantinya dijadikan sampel yakni kelas yang memiliki nomor klasifikasi dengan jumlah kesesuaian tertinggi dan kelas yang mempunyai nomor klasifikasi tidak sesuai tertinggi.

Menurut penjelasan di atas ditarik kesimpulan yaitu dari 96 koleksi, tingkat kesesuaian diperoleh dari analisis data persentase sekitar $61-80 \%$ termasuk dalam kriteria tinggi yakni 80\%, dan tingkat tidak sesuai koleksi sekitar 0-20\% dalam kriteria sangat rendah yaitu $20 \%$.

Kesesuaian nomor klasifikasi terbanyak yaitu kelas 600. Sekitar 81-100\% dikatakan sangat tinggi menurut analisis data persentase. Untuk 0-20\% ditafsirkan sangat rendah berdasarkan analisis data persentase. Pada kelas 600 untuk ketidaksesuaian koleksi menurut divisi dapat dilihat sebagai berikut,

Tabel 11.

Jumlah ketidaksesuaian nomor klasifikasi kelas 600 digolongkan berdasarkan divisi

\begin{tabular}{|c|c|c|c|c|}
\hline No. & Divisi & Judul & $\begin{array}{c}\text { Nomor } \\
\text { Klasifikasi } \\
\text { Sampel }\end{array}$ & $\begin{array}{c}\text { Nomor } \\
\text { Klasifikasi } \\
\text { yang Sesuai }\end{array}$ \\
\hline \multirow[t]{7}{*}{1.} & $650-659$ & Manajemen Playanan Prima & 651 & 651.3 \\
\hline & & $\begin{array}{l}\text { Manajemen Perkantoran, Efektif, } \\
\text { Efisien dan Professional }\end{array}$ & 651 & 651.3 \\
\hline & & Manajemen Sumber Daya Manusia & 658 & 658.3 \\
\hline & & Pengantar Manajemen & 658.04 & 658 \\
\hline & & $\begin{array}{l}\text { Strategi Pemerintah, Manajemen } \\
\text { Organisasi Publik }\end{array}$ & 658.04 & 658.1 \\
\hline & & Prinsip-Prinsip Manajemen & 658.015 & 658 \\
\hline & & Teori Pengembangan Organisasi & 658.31 & 658.1 \\
\hline
\end{tabular}

Sumber: Data diolah Mei 2021

Berdasarkan tabel 11 dapat uraikan bahwa nomor klasifikasi pada kelas 600 memiliki jumlah ketidaksesuaian tertinggi dibagi menjadi 1 divisi dari kelas tersebut. Dapat dilihat untuk memperjelas tabel pada contoh, judul koleksi Manajemen Pelayanan Prima dengan nomor klasifikasi 651, sedangkan nomor klasifikasi yaitu yang sesuai 651.3, kedua nomor klasifikasi tersebut terdapat perbedaan seksi pada nomor klasifikasi yang sesuai. Nomor klasifikasi sampel 
yaitu 651 menjelaskan tentang Office Services/Layanan Kantor. Untuk memahami nomor klasifikasi dapat dilihat yang sesuai pada penjelasan:

Judul

: Manajemen Pelayanan Prima

Subjek

Keterangan

: Manajemen

: 651.3 Office Management/Manajemen Kantor, Manajemen

Perkantoran

Kelaskan di sini layanan perkantoran, kegiatan tata usaha, kegiatan kesekretarian. Termasuk stenografer, tukang ketik, sekretaris.

Nomor Klasifikasi : 651.3

\section{Nomor Klasifikasi Koleksi Perpustakaan Fakultas Kehutanan Universitas Lancang Kuning}

Tabel 12.

Jumlah nomor klasifikasi koleksi umum Perpustakaan Fakultas Kehutanan Unilak yang sesuai dan tidak sesuai

\begin{tabular}{|c|c|c|c|c|c|c|}
\hline \multirow{2}{*}{ No. } & \multirow{2}{*}{ No. kelas } & \multirow{2}{*}{ Jumlah } & \multicolumn{2}{|c|}{ Sesuai } & \multicolumn{2}{|c|}{ Tidak sesuai } \\
\hline & & & $\mathbf{F}$ & $\%$ & $\mathbf{F}$ & $\%$ \\
\hline 1. & 000 & 5 & 4 & $80 \%$ & 1 & $20 \%$ \\
\hline 2. & 100 & 2 & 0 & $0 \%$ & 2 & $100 \%$ \\
\hline 3. & 200 & 3 & 3 & $100 \%$ & 0 & $0 \%$ \\
\hline 4. & 300 & 13 & 10 & $77 \%$ & 3 & $23 \%$ \\
\hline 5. & 400 & 0 & 0 & 0\% & 0 & $0 \%$ \\
\hline 6. & 500 & 19 & 9 & $47 \%$ & 10 & $53 \%$ \\
\hline 7. & 600 & 53 & 33 & $62 \%$ & 21 & $40 \%$ \\
\hline 8. & 700 & 0 & 0 & 0\% & 0 & $0 \%$ \\
\hline 9. & 800 & 0 & 0 & $0 \%$ & 0 & $0 \%$ \\
\hline 10. & 900 & 0 & 0 & 0\% & 0 & $0 \%$ \\
\hline \multicolumn{2}{|r|}{ Jumlah } & 95 & 59 & \multicolumn{3}{|c|}{36} \\
\hline \multicolumn{2}{|c|}{ Total \% } & & $62 \%$ & \multicolumn{3}{|c|}{$38 \%$} \\
\hline
\end{tabular}

Sumber: Data diolah juni 2021

Dari tabel 12 dapat diuraikan keseluruhan sampel yang diteliti di Perpustakaan Fakultas Kehutanan ditemukan kelas yang mempunyai total kesesuaian dan tidak sesuai dengan jumlah $f$ yang bervariasi dari 10 kelas utama. Pada keterangan tersebut peneliti hanya akan mengambil 2 kelas utama yang akan diambil sampel yakni kelas memiliki nomor klasifikasi ketidaksesuaian tertinggi dan kelas yang memiliki nomor klasifikasi yang mempunyai jumlah kesesuaian tertinggi.

Berdasarkan paparan di atas diketahui bahwa keseluruhan koleksi yang sejumlah 95 koleksi, tingkat kesesuaian dikatakan tinggi yaitu 62\% diamati dari analisis data persentase sekitar 61-80\%, sedangkan tingkat ketidaksesuaian koleksi sekitar 21-40\% termasuk dalam kriteria rendah ialah $38 \%$.

Kesesuaian nomor klasifikasi terbanyak terdapat di kelas 600. Berdasarkan analisis persentase data dapat dikatakan tinggi sekitar 61-80\%. Untuk ketidaksesuaian nomor klasifikasi 
Palimpsest: Journal of Information and Library Science Vol 12, Issue 2, (2021), page 81-84

terbanyak terdapat pada kelas 600 berdasarkan analisis sekitar $21-40 \%$ data persentase dikatakan rendah. Ketidaksesuaian koleksi di kelas 600 dapat dilihat berdasarkan divisi oleh tabel 19 berikut,

Tabel 13.

Jumlah ketidaksesuaian nomor klasifikasi kelas 600 digolongkan berdasarkan divisi

\begin{tabular}{|c|c|c|c|c|}
\hline No. & Divisi & Judul & $\begin{array}{c}\text { Nomor } \\
\text { Klasifikasi } \\
\text { Sampel }\end{array}$ & $\begin{array}{c}\text { Nomor } \\
\text { Klasifikasi } \\
\text { yang Sesuai }\end{array}$ \\
\hline \multirow[t]{20}{*}{1.} & $630-639$ & Pengendalian Hama Penyakit Padi & 633.189 .6 & 632.9 \\
\hline & & Bertanam Kacang Tanah & 633.659 .6 & 633.3 \\
\hline & & $\begin{array}{l}\text { Analisis Lanskap Agroforestri Konsep, } \\
\text { Metode dan Pengelolaan Agroforestri } \\
\text { Skala Lanskap dengan Studi Kasus } \\
\text { Indonesia, Filipina, Laos, Thailand, } \\
\text { dan Vietnam }\end{array}$ & 634.091 .6 & 634.99 \\
\hline & & Berkebun Durian ala Petani Thailand & 634.6 & 634.659 .3 \\
\hline & & $\begin{array}{l}\text { Bertanam Mangga ala Petani Thailand } \\
\text { Anatomi Kayu: Pengantar Sifat Kayu }\end{array}$ & 634.655 & 634.459 .3 \\
\hline & & sebagai Bahan Baku & 634.97 & 674.1 \\
\hline & & $\begin{array}{l}\text { Budidaya Sengon Buto: Prospek Cerah } \\
\text { disertai Analisis Hasil }\end{array}$ & 634.973 & 582.15 \\
\hline & & $\begin{array}{l}\text { Budidaya dan Panen Sayuran Dataran } \\
\text { Rendah }\end{array}$ & 635 & 635.145 \\
\hline & & Bawang Putih Dataran Rendah & 635.25 & 635.214 .5 \\
\hline & & Bertanam Kedelai & 635.659 .6 & 633.3 \\
\hline & & Budidaya Anggrek & 635.934 .15 & 584.4 \\
\hline & & Berternak Burung Kenari & 636.686 .2 & 636.6 \\
\hline & & Anggur Dalam Pot & 638.8 & 634.8 \\
\hline & & $\begin{array}{l}\text { Budidaya Ikan Air Tawar: Ikan } \\
\text { Gurami, Ikan Nila, Ikan Mas }\end{array}$ & 639.21 & 639.31 \\
\hline & & Budidaya Ikan di Jaring Terapung & 639.3 & 639.2 \\
\hline & & Budidaya Ikan Nila & 639.34 & 639.31 \\
\hline & & Budidaya Gurami & 639.37 & 639.31 \\
\hline & & Budidaya Tripang & 639.373 & 639.32 \\
\hline & & Budidaya Ikan Lele & 639.375 .2 & 639.2 \\
\hline & & Arwana & 639.375 .8 & 597.4 \\
\hline 2. & $660-669$ & Budidaya dan Penyuluhan Nilam & 661.806 & 639.31 \\
\hline
\end{tabular}

Sumber: Data diolah juni 2021

Menurut tabel 13 dijelaskan bahwa yang mempunyai ketidaksesuaian tertinggi terdapat pada nomor kelas 600. Kelas tersebut kemudian dibagi 2 divisi pada tabel di atas untuk memperjelas dapat dilihat pada judul koleksi contoh, Pengendalian Hama Penyakit Padi dengan nomor klasifikasi 633.189.6, sedangkan nomor klasifikasi yaitu yang sesuai 632.9, dari nomor klasifikasi tersebut ditemukan perbedaan seksi nomor klasifikasi yang sesuai. Nomor klasifikasi sampel yaitu 633.189.6 menjelaskan tentang Cereals/Sereal Biji-bijian, Kelaskan di sini gandum, jagung, oat, maizena, padi beras, lihat juga 664.7 untuk teknologi pembuatan makanan dari padi dan biji-bijian. Untuk penjelasan dapat dilihat nomor klasifikasi yang sesuai di bawah ini, 
Judul : Pengendalian Hama Penyakit Padi

Subjek

: Hama

Keterangan

\section{: 632.9 General Topics of Pests Diseases Control/Pembasmian Hama pada Tanaman Pertanian.}

Kelaskan di sini pembasmian hama pada tumbuhan pertanian. Termasuk pemakaian pestisida, insektisida, fungisida, DDT, fumigasi hama. Lihat juga 363.7 untuk hama ditinjau dari segi permasalah lingkungan. Lihat juga 614.4 untuk fumigasi kedokteran. Lihat juga 668.6 untuk teknologi bahan kimia pertanian, industry pestisida

Nomor Klasifikasi : 632.9

Persamaan dari penelitian terdahulu yang dilakukan oleh Dwiyantoro pada tahun 2016 dan yang peneliti lakukan adalah keduanya membahas tentang e-DDC. Perbedaan dari penelitian oleh Dwiyantoro dengan penelitian oleh penulis adalah penelitian sebelumnya dilakukan pada tahun 2016 dan meneliti empat perpustakaan yaitu UPT Perpustakaan Unilak, Perpustakaan FIB, Perpustakaan Fakultas Hukum, dan Perpustakaan FIA, lalu data yang diperoleh dari tahun 2016 ke bawah. Sedangkan, penelitian yang dilakukan oleh penulis dilakukan pada tahun 2020, tepatnya di enam perpustakaan di lingkungan Unilak, yaitu UPT Perpustakaan Unilak, Perpustakaan FIB, Perpustakaan Fakultas Hukum, Perpustakaan Fekon, Perpustakaan FIA, dan Perpustakaan Fakultas Kehutanan, lalu data yang diperoleh dari tahun 2017-2020.

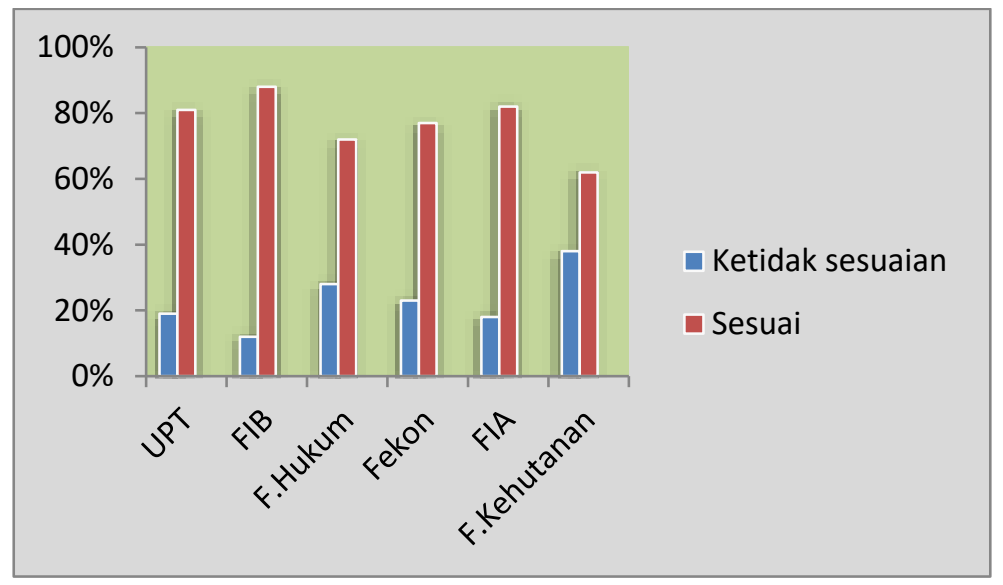

\section{Grafik 1.}

Persentase tingkat kesesuaian nomor klasifikasi perpustakan di lingkungan Unilak

Dari grafik 1 dapat dijelaskan bahwa tingkat kesesuaian nomor klasifikasi dari yang tertinggi hingga terendah yaitu terdapat di Perpustakaan FIB dengan jumlah 88\%, Perpustakaan FIA dengan jumlah $82 \%$, UPT Perpustakaan Unilak dengan jumlah $81 \%$, Perpustakaan Fakultas Ekonomi dengan jumlah 77\%, Perpustakaan Fakultas Hukum dengan jumlah $72 \%$ dan Perpustakaan Fakultas Kehutanan dengan jumlah 62\%. Sedangkan ketidak kesesuaian nomor klasifikasi dari yang tertinggi hingga terendah yaitu terdapat di Perpustakaan Fakultas Kehutanan dengan jumlah 38\%, Perpustakaan Fakultas Hukum dengan jumlah 28\%, Perpustakaan Fakultas Ekonomi dengan jumlah 23\%, UPT Perpustakaan Unilak dengan jumlah 19\%, Perpustakaan FIA dengan jumlah 18\% dan Perpustakaan FIB dengan jumlah 12. 
Palimpsest: Journal of Information and Library Science Vol 12, Issue 1, (2021), page 83-84

\section{Kesimpulan}

Berdasarkan hasil penelitian berjudul Analisis Penggunaan e-DDC dalam Pengklasifikasian Bahan Pustaka di Perpustakaan Lingkungan Universitas Lancang Kuning, dapat disimpulkan bahwa dari keenam perpustakaan yang diteliti seluruhnya untuk sebagai acuan dalam menentukan nomor klasifikasi koleksi perpustakaan menggunakan aplikasi e-DDC. Dari hasil penelitian yang peneliti lakukan diperoleh bahwa jumlah kesesuaian nomor klasifikasi koleksi yang tertinggi berada di Perpustakaan FIB yang berjumlah 86 koleksi (88\% tergolong dalam kriteria sangat tinggi), sedangkan jumlah kesesuaiaan nomor klasifikasi koleksi yang terendah berada di Perpustakaan Fakultas Kehutanan yang berjumlah 59 koleksi (62\% tergolong dalam kriteria tinggi).

Dari wawancara yang peneliti telah lakukan terhadap keenam informan maka dapat disimpulkan bahwa terkait penggunaan aplikasi e-DDC sangat membantu, memudahkan, dan dalam segi waktu lebih efisien dalam melakukan kegiatan klasifikasi. Namun bagi beberapa informan dalam kegiatan menentukan nomor klasifikasi untuk lebih akuratnya mereka menggunakan DDC tercetak juga sebagai pedomannya. Terkait ketidaksesuaian nomor klasifikasi, menurut hasil wawancara yang beberapa informan yang telah peneliti lakukan ternyata kesalahan dominan yang terjadi karena kurangnya ketelitian pada saat menentukan subjek pada bahan pustaka dan kurangnya pemahaman terhadap ilmu klasifikasi, tetapi informan 6 mengungkapkan bahwa untuk ketidaksesuaian nomor klasifikasi yang terjadi karena ketika kegiatan klasifikasi diserahkan kepada anak yang sedang magang yang bisa dikatakan masih kurang dalam melakukan kegiatan klasifikasi.

\section{Daftar Pustaka}

Amelia, Vita, and Triono Dul. (2016). Sitiran, Analisis Jurnal, Pada Lingkungan, D I Periode, Unilak. 3 (2).

Berawi, Imran. (2012). Mengenal Lebih Dekat Perpustakaan Perguruan Tinggi. Jurnal Iqra'. 6 (1).

Dwiyantoro, Nining Sudiar, and Vita Amelia. 2018. Evaluasi Penggunaan E-DDC Dalam Mengklasifikasi Bahan Pustaka Di Lingkungan Perpustakaan Universitas Lancang Kuning. Jurnal Pustaka Budaya. Vol 5, No (1): 7-18. Diunduh pada tanggal 9 September 2020.

Mustafa, Jamal Ibrahim. (2016). Analisis Sistem Klasifikasi Bahan Pustaka Di Perpustakaan Fakultas Ushuluddin Dan Filsafat Universitas Islam Negeri Alauddin Makkasar. Universitas Islam Negeri Alauddin Makassar.

Nugroho, Muhammad Bagus. 2015. "Mencermati Nomor-Nomor Opsional (Optional Number) Dalam Sistem Klasifikasi Persepuluhan Dewey Edisi 23 (DDC Edition 23)." Record and Library Journal 1(1): 1689-99.

Nurfatah, Ahmad, Ute Lies Khadijah, and Evi Rosfiantika. (2016). Pengolahan Bahan Pustaka Karya Cetak Di Kantor Arsip Dan Perpustakaan Daerah (KAPD). Jurnal Kajian Informasi dan Perpustakaan. 4 (1). Diunduh pada tanggal 25 November 2020.

Rohman, Asep Saeful, Prijana Prijana, and Samson CMS. (2018). "Perluasan Notasi Dewey Decimal Classification (DDC) Tentang Bahasa Dan Susastra Sunda." Jurnal Kajian Informasi dan Perpustakaan 5(2): 155.

Rotmianto, Mohammad. (2015). E-DDC (Electronic-Dewey Decimal Classification) as a Freeware Classification Number Finder Based on DDC: History and Development. 22 (3). 
Palimpsest: Journal of Information and Library Science Vol 12, Issue 2, (2021), page 84-84

Diunduh pada tanggal 30 September 2020.

Saputro, Bayu Indra. (2017). "Penerapan Sistem Klasifikasi Perpustakaan Arkeologi Di Perpustakaan Balai Arkeologi Daerah Istimewa Yogyakarta.” Berkala Ilmu Perpustakaan dan Informasi 13(2): 107.

Siregar, Syofian. (2013). Metode Penelitian Kuantitatif, Dilengkapi Dengan Perbandingan Perhitungan Manual \& SPSS. Jakarta.

Sukandarrumidi. (2002). Metodologi Penelitian: Petunjuk Praktis Untuk Peneliti Pemula. Yogyakarta : Gadjah Mada University Press.

Towa P. Hamakonda. (2012). Pengantar Klasifikasi Persepuluhan Dewey. Jakarta: Libri.

Wiji, Suwarno. (2007). Dasar-Dasar Ilmu Perpustakaan, Sebuah Pendekatan Praktis. Yogyakarta : Ar-Ruzz Media. 